\title{
Sengkalan Memet Pada Cagar Budaya Cirebon
}

\author{
Agus Dody Purnomo ${ }^{1 *}$, Ardianto Nugroho ${ }^{2}$, Anggoro Cipto Ismoyo ${ }^{3}$ \\ Program Studi Desain Interior, Fakultas Industri Kreatif, Universitas Telkom
}

\begin{abstract}
In Javanese culture, symbol has become a common media to describe historical events. One of the symbol used to describe it, is Sengkalan Memet. Sengkalan Memet consist of three elements, visual, Sengkalan sentences, and the number of years of a important events happening. Sengkalan Memet consists of pictures configuration, statue, or even a building. Keraton Kasepuhan Cirebon dan Taman Sunyaragi are one of cultural heritage places that have Sengkalan Memet. The study is to explore Sengkalan Memet and the meaning in the Keraton Kasepuhan Cirebon and Taman Sunyaragi. The methodology implemented in this study is using a descriptive qualitative method. This study is expected to be an added value for artists, architects, designers and creative industries to take advantage of local wisdom. Furthermore this study can be used as an approach for design in this global era.
\end{abstract}

\section{Keywords}

sengkalan memet, candrasengkala, heritage, Cirebon 


\section{Sengkalan Memet Pada Cagar Budaya Cirebon}

Agus Dody Purnomo

\section{PENDAHULUAN}

Kehidupan manusia sangat akrab dan tidak bisa lepas dalam menggunakan simbol-simbol. Seperti yang dikemukakan oleh antropolog Ernst Cassirer bahwa manusia sebagai Animal Symbolicum, atau bisa diartikan sebagai hewan yang menggunakan simbol. Simbol dan tanda atau yang sering dikenal sebagai 'bahasa' dipakai oleh manusia sebagai sarana komunikasi [1, 2]. Bahasa lisan, bahasa tulis, maupun bahasa visual menggunakan beragam simbol. Begitupula dalam budaya Jawa, penggunaan simbol sudah sangat akrab. Masyarakat Jawa juga dipadati tata cara hidup simbolis, mengungkapkan segala sesuatunya dengan cara hidup dan indah. Dan simbol dipakai sebagai media perantara dalam menggambarkan sesuatu[2, 3]. Salah satu contohnya dimana mereka mengenal dan menggunakan 'Sengkalan' untuk mengingat peristiwa-peristiwa atau kejadian-kejadian penting bersejarah, misalnya: kelahiran, kematian, perayaan, peresmian gedung atau bangunan bersejarah, dan kejadian penting lainnya. Sengkalan juga sebagai ungkapan kesadaran kesejarahan orang Jawa terhadap peristiwa penting dalam siklus kehidupan[2, 4]. Sebagai contoh seperti yang terdapat pada Sengkalan Lamba yang berbunyi "Sirna Ilang Kertaning Bumi" (dalam bahasa Indonesia "hilang musnah kemakmuran bumi"). Sirna = 0, llang = 0, Kertaning = 4, Bumi = 1, tahun 1400 Saka / 1478 M menjadi tahun penanda tahun kematian Raja Majapahit terakhir Bhre Kertabumi sekaligus penanda keruntuhan kerajaan Majapahit. Contoh lainnya yakni tahun berdirinya Keraton Yogyakarta yang ditandai dengan Sengkalan Memet yang terpahat pada dinding atas keraton Yogyakarta, 'Dwi Naga Rasa Tunggal.'Sengkalan berupa relief dua ekor naga yang saling berbelitan ekornya di tengah-tengah. Dwi $=2$, Naga $=8$, Rasa $=6$, Tunggal $=1$, jadi 1682 Saka / 1760 M merupakan tahun berdirinya keraton Yogyakarta.

Sengkalan atau kronogram adalah sederetan kata atau kalimat yang mengandung makna nilai angka tertentu dan biasanya mengarah kepada angka tahun. Deretan kata atau kalimat tersebut juga memiliki watak bilangan menurut kenyataan keadaannya[4-8]. Istilah Sengkalan sendiri berasal dari bahasa Sansekerta "syakukala" yang kemudian juga digunakan dalam bahasa Jawa Kuna yang berarti perhitungan waktu menurut Tahun Saka. Saka adalah perubahan dalam bahasa Jawa dari kata Sansekerta "syaka", di India artinya bangsa Scyth [2, 9].

Berdasarkan peredaran tahunnya Sengkalan dibedakan menjadi dua yakni: Suryasengkala dan Candrasengkala. Suryasengkala berdasarkan tahun peredaran matahari (tahun syamsiah) dan lebih dahulu dipergunakan dimana tahun yang dipakai adalah Saka (Hindu Jawa). Suryasengkala berlangsung hingga berakhirnya masa kerajaan Majapahit. Sedangkan Candrasengkala berdasarkan tahun peredaran bulan (tahun kamariyah) mulai dipergunakan pada masa kerajaan Demak untuk tahunnya berlaku perhitungan tahun Hijriah. Saat Sultan Agung Hanyakrakusuma berkuasa atas kerajaan Mataram Islam, beliau memadukan keduanya menjadi tahun Jawa atau dikenal Anno Javanica. Penggunaan sistem tahun Jawa juga dipakai dalam penulisan Babad Cirebon $[5,10]$. Pada kalender Saka dimulai pada tahun 78 M, yang bertepatan dengan datangnya seorang tokoh mitologi dari India yang bernama Aji Saka pencipta huruf Jawa[4]. Sehingga saat menulis tahun Saka menjadi tahun Masehi tinggal ditambahkan 78 tahun.

Jenis Sengkalan dibedakan menjadi tiga bentuk yakni Sengkalan Lamba, Sengkalan Sastra, dan Sengkalan Memet. Sengkalan Lamba diwujudkan dengan susunan kata / kalimat tanpa adanya rupa atau gambar. Sedangkan Sengkalan Sastra lebih berbentuk aksara Jawa beserta sadangannya atau abjad, yang biasa digunakan pada ukir-ukiran hiasan keris dan ornamen. Sedangkan yang ketiga adalah Sengkalan Memet lebih berbentuk rupa, gambar, patung, relief, ornamental, bahkan bangunan[4, 6-8, 11]. Istilah 'Memet' sendiri artinya rumit, hal ini dikarenakan tampilan Sengkalan tidak langsung berbentuk susunan kata namun lebih kepada bentuk visual. Dengan demikian saat ingin mengetahui angka tahunnya harus diterjemahkan lebih dulu ke dalam Sengkalan Lamba, setelah itu baru dicari nilai dari kata yang tersusun 
untuk mencari terjemahan angkanya. Jadi khusus Sengkalan Memet mempunyai tiga unsur yang membentuknya, yakni gambar atau bentukrupa (visual), kalimat Sengkalan, dan angka tahun yang diwakili. Jadi Sengkalan Memet merupakan bentuk kesenian masyarakat Jawa yang unik karena merupakan gabungan dari seni rupa (termasuk di dalamnya arsitektur), sastra, sejarah, dan bahkan semiotika[5, 9].

Sengkalan tersusun dalam suatu kalimat atau rangkaian kata-kata yang masing-masing kata mengandung makna nilai angka tahun. Cara membaca angkanya harus dari kanan ke kiri atau dari belakang ke depan. Kata pertama dan kedua dalam kalimat sengkalan merupakan angka satuan dan puluhan dari tahun terjadinya peristiwa. Sedangkan kata ketiga dan paling akhir dari kalimat sengkalan menandai abad ketika peristiwa itu terjadi[4, 11]. Seperti contoh peristiwa jatuhnya kerajaan Majapahit, diperingati dengan sengkalan: Sirna (0) Ilang (0) Kertaning (4) Bumi (1), yang berarti 1400 tahun Saka atau 1478 Masehi.

Sengkalan atau sebutan lainnya 'Candrasengkala' (pada masa kerajaan Islam berkuasa), mempunyai makna 'tetenger' atau pertanda saat atau waktu tiba, selain dicantumkan pesan-pesan lain, yang bernilai falsafah atau cita-cita atau harapan penghuni di masa yang akan datang. Candrasengkala biasanya berbentuk ukir-ukiran pada bagian bangunan yang dimaksudkan oleh pesan tersebut, tetapi ada kalanya pula diungkapkan dalam bentuk bangunan secara utuh, dengan bahasa bangunan yang mempunyai bagian-bagian kepala, badan, dan kaki. Candrasengkala selain diterjemahkan dalam bentuk angka-angka namun juga berupa pesan-pesan falsafah yang memuat banyak ajaran-ajaran, yang artinya bagi mereka yang berada di dalam bangunan tersebut[3].

Candrasengkala terdapat juga di beberapa cagar budaya Cirebon seperti keraton dan taman. Keraton Kasepuhan Cirebon merupakan bangunan cagar budaya yang masih berdiri dan terpelihara dengan baik[12]. Keraton yang dibangun dengan akulturasi budaya beragam, mulai HinduBudha, Islam, China, dan bahkan Eropa. Budaya Hindu mengawali dalam pembangunan Keraton Kasepuhan Cirebon pada masa awal. Hal ini juga termuat dalam Babad Cirebon episode XVI dan XVII yang mengemukakan tentang hubungan Cirebon dengan Demak. Dalam mempererat hubungan Sultan Demak sekaligus sebagai tanda terima kasih terhadap gurunya yakni Sunan Gunung Jati, Sultan Demak membangun benteng (kutha) dan keraton di Cirebon dengan mengirimkan ahli bangunan yang berasal dari Majapahit dibawah pimpinan Raden Sepet[10].

Pendapat lainnya yang juga menguatkan tentang pengaruh budaya Hindu pada seni bangunan di Cirebon adalah pendapat FDK Bosch. Bosch menyatakan bahwa kepurbakalaan periode Islam (milik keraton) yang ada di Cirebon tidak memperlihatkan hal baru melainkan hanya meniru seni bangunan yang berkembang pada masa Jawa Timur dalam hal ini Majapahit. Lebih jauh ia beranggapan bahwa para pemeluk Islam di Jawa tidak mempunyai daya kreasi untuk menciptakan pembaharuan. Para rajanya membangun keraton berdasarkan gaya dan konsep lama[13]. Sebagai contoh: gapura Bentar yang ada di komplek Keraton Kasepuhan Cirebon dan komplek Taman Sunyaragi seperti gapura Wringin Lawang di Mojokerto, Jawa Timur. Dari dua hal tersebut kemungkinan besar bentuk Keraton Kasepuhan Cirebon memiliki kesamaan dengan keraton yang berada di Jawa Tengah dan Jawa Timur. Seperti juga pada keratonkeraton di Jawa pada umumnya, Keraton Kasepuhan Cirebon juga terdapat Sengkalan Memet (Candrasengkala) yang berfungsi sebagai 'tetenger' yang nantinya dapat diwariskan kepada generasi berikutnya.

Penelitian ini mengkaji tentang Sengkalan Memet beserta maknanya yang terdapat di Keraton Kasepuhan Cirebon dan Taman Sunyaragi. Selain itu diharapkan hasil kajian ini juga dapat menjadi sumber referensi yang menginspirasi bagi desainer, arsitek, maupun seniman jaman sekarang.

\section{METODE PENELITIAN}

Penelitian ini menggunakan metode deskriptif kualitatif. Hal ini mengingat obyek penelitian merupakan artefak dari bangunan tradisional dan bersejarah yang dimiliki oleh Keraton Kasepuhan Cirebon. Sejarah pembangunan keraton yang bersentuhan dengan budaya Jawa baik dari kerajaan Majapahit, Demak, maupun Mataram Islam. Lokasi penelitian yang dipilih yakni Keraton Kasepuhan Cirebon dan Taman Sunyaragi. Keduanya merupakan bangunan cagar budaya yang menyimpan Sengkalan Memet.

Pengumpulan data dilaksanakan melalui teknik wawancara dan pengamatan di lapangan. Penga-matan lapangan dilakukan di komplek Keraton Kasepuhan Cirebon, jalan Kasepuhan, Lemah-wungkuk, Cirebon. Sedangkan lokasi Taman Sunyaragi terletak di luar komplek keraton tepatnya di sebelah Barat Daya keraton di jalan Sunyaragi, Kesambi, Cirebon. Taman Sunyaragi disebut juga Goa Sunyaragi merupakan 
tamansari milik Keraton Kasepuhan Cirebon. Kunjungan pertama merupakan survei awal untuk pengumpulan data sekaligus merekam artefak-artefak yang akan dikaji. Dan pada kunjungan berikutnya untuk melengkapi data lapangan berikutnya. Dari data yang diperoleh dilakukan analisis, sedangkan wawancara dilakukan pada setiap kunjungan lapangan pada beberapa narasumber. Selain itu juga dilakukan pengumpulan data sekunder melalui literatur baik cetak maupun internet.

\section{HASIL DAN ANALISIS}

\section{Pengaruh Budaya Hindu dan Jawa}

Secara etnografis, kebudayaan Jawa dibagi dalam beberapa sub daerah antara lain: Negarigung, Banyumas, Bagelen, Pesisir Kilen, Pesisir Wetan, Mancanegari, dan Tanah Sabrang Wetan. Masing-masing memiliki karakteristik budaya yang akhirnya menghasilkan keragaman budaya Jawa[14]. Cirebon merupakan wilayah Pesisir Kilen dan berkarakter budaya dengan unsur-unsur religiusnya khususnya pengaruh budaya Islam. Namun sebelumnya wilayah Cirebon juga merupakan bagian dari kerajaan Pajajaran yang berlatar belakang Hindu. Begitupula Sunan Gunung Jati sebagai pemimpin serta penyebar agama Islam di Jawa Barat merupakan anak dari Nyi Dalem Santang atau cucu dari Prabu Siliwangi raja Pajajaran.

Berkaitan dengan seni bangunan dimana saat raja Cirebon membangun keraton berdasarkan gaya serta konsep lama. Hal ini dikarenakan alam pikiran lama yang banyak melatar belakangi gaya seni bangunan masa pra Islam (jaman Hindu) tetap hidup dan didukung di Kesultanan Cirebon saat itu[13, 15]. Misalnya tentang kesejajaran antara alam semesta dan alam manusia (konsep kosmo magis), hal ini untuk mengabsahkan otoritas raja (sultan) sebagai penguasa. Seperti umumnya dalam kepercayaan pra Islam keberadaan gunung (Maha-meru) dianggap sebagai tempat tinggal para dewa, tempat sakral, tempat penguasa alam, dan sebagainya. Sedangkan secara mikro-kosmos penguasa alam manusia (negara, kerajaan) adalah raja/sultan yang bersemayam di keraton.

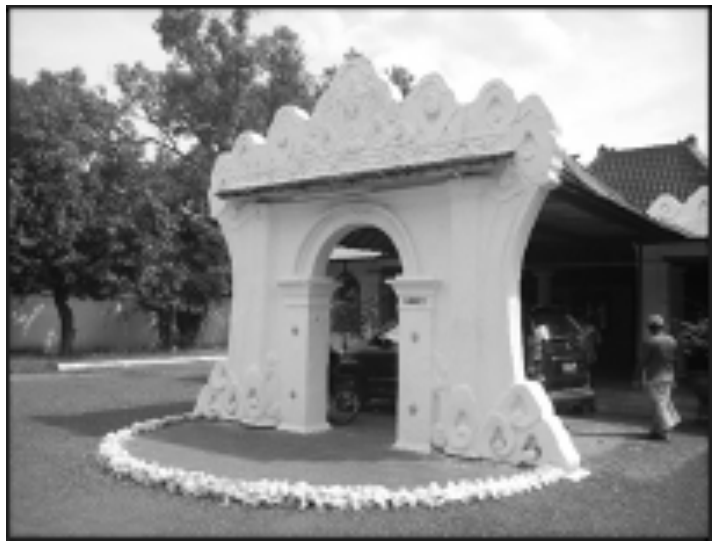

Gambar 1 Ornamen Megamendung dan Wadasan pada gapura Kutagara Wadasan

Dilihat dari pola tata letak bangunan keraton mulai dari depan (pelataran Siti Hinggil) semakin ke belakang hingga bangunan inti keraton, memiliki kontur permukaan tanah semakin tinggi ke belakang. Tempat yang paling tinggi menandakan tempat yang paling suci dimana raja beserta keluarganya bersemayam. Ornamen Megamendung dan Wadasan gapura Kutagara Wadasan merupakan simbol dunia atas dan dunia bawah melengkapi gambaran alam Mahameru. Pola bentuk ornamen Wadasan cenderung meruncing pada bagian atas yang mengesankan bentuk alami gunung. Tidak heran jika pada lingkungan Keraton Kasepuhan Cirebon maupun Taman Sunyaragi selalu meng-hadirkan gunung baik secara miniatur maupun simbolik. Hal lain yang masih terkait pada seni bangunannya yakni keterlibatan ahli bangunan. Pembangunan Keraton Kasepuhan Cirebon melibatkan ahli bangunan dari Majapahit yang dipimpin oleh Raden Sepet. Keterlibatan mereka tentunya membawa pengaruh juga dalam proses pembangunan keraton yang mewarisi budaya Majapahit. 
Latar belakang historis tersebut menghasilkan akulturasi budaya yang berkembang di keraton Cirebon, termasuk di dalamnya penggunaan Sengkalan yang notabene pengaruh dari kerajaan Majapahit dan budaya Jawa. Sengkalan kemudian meng-alami pembaharuan yakni perubahan Suryasengkala menjadi Candra-sengkala oleh Sultan Agung raja Mataram. Dan Candrasengkala merupakan sebutan dalam bahasa Jawa Baru. 'Candra' bukan lagi berarti bulan yang menandai tahun Qomariah melainkan diberi arti deskripsi, pemaparan, pemerian [5, 9].

\section{Figur Binatang Sengkalan Memet}

Beberapa Sengkalan Memet yang terdapat di Keraton Kasepuhan Cirebon dan Taman Sunyaragi berupa relief dan patung. Umumnya figur yang ditampilkan dalam Sengkalan Memet yakni figur binatang. Binatang-binatang yang berasal dari mitos budaya pra Islam, antara lain: banteng, gajah (liman), burung garuda, dan ular (bhujangga).

Sebenarnya penggambaran figur binatang di Nusantara sudah ada sejak jaman prasejarah. Sebagai contoh pada dinding-dinding goa jaman prasejarah banyak ditemukan gambar cadas tentang figur binatang selain cap telapak tangan manusia purba. Pada dinding goa jaman prasejarah terdapat pula siluet dari bekas cetakan kaki, beberapa figur bentuk manusia dan binatang laut, serta banyak tanda-tanda atau simbol, diantaranya adalah sebuah gambar bulan sabit dan desain-desain lainnya yang kurang dikenal. Gambar-gambar tersebut berfungsi sebagai media berkomunikasi dalam berkata dan bercerita saat itu[16, 17]. Teknik peng-gambaran figur binatang mengalami perkembangan pada jaman Hindu-Budha dimana tidak hanya berupa relief (dua dimensi) namun juga bentuk patung (tiga dimensi) seperti yang terdapat pada candi-candi.

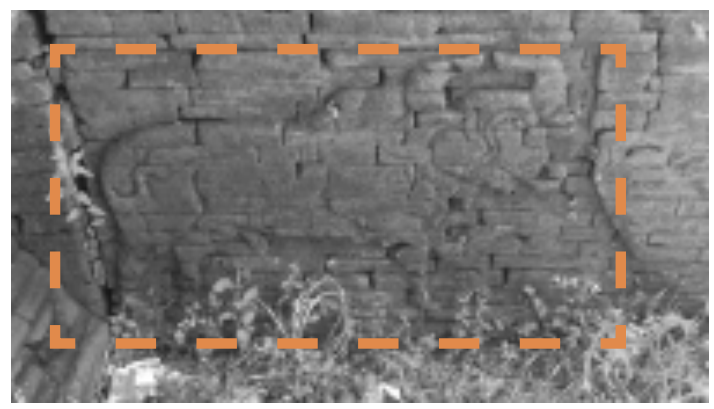

Gambar 2 Relief banteng gapura Bentar Keraton Kasepuhan Cirebon

Sengkalan Memet yang pertama akan dibahas yakni yang berkaitan dengan figur banteng. Candrasengkala ini terdapat pada dinding gapura Bentar (gapura Banteng) yang terletak di belakang Siti Hinggil Keraton Kasepuhan Cirebon. Sengkalan Memet berupa relief binatang banteng yang distilasi. Relief berbahan batu bata merah dan terletak pada sisi kanan-kiri anak tangga gapura. Candrasengkala tersebut berbunyi "Kuta Bata Tinata Banteng". Kuta:1, Bata:5, Tinata:4, Banteng:1 sehingga diartikan adalah tahun dibangun 1451 Saka atau 1529 M. Dalam Candra-sengkala tersebut, figur banteng berwatak angka 1 karena binatang tersebut merupakan kendaraan dewa, juga dianggap hewan suci.

Banteng merupakan hewan sejenis dengan kerbau dan sapi jantan yang memiliki tanduk. Pada masyarakat adat di tanah air, seperti masyarakat Batak dan Toraja, mereka sering memakai binatang tersebut untuk kegiatan ritual. Secara simbolik pada bagian kepala/tanduknya menjadi simbol secara artifisial pada bentuk atap rumah tradisional maupun ornamen dindingnya.

Dalam mitologi Hindu baik di Jawa dan Bali mengenal makhluk-makhluk bersayap yang khas, antaralain: singa bersayap, ular bersayap, dan banteng bersayap[16]. Khusus binatang banteng (sapi jantan) disebut juga nandi merupakan binatang kendaraan dewa Siwa. Sapi dianggap binatang suci bagi masyarakat Hindu. Begitupula dalam dunia pewayangan, dikenal dengan tokoh Handaka Murti berupa banteng sapi hutan. Tokoh lainnya adalah Jatasura yakni raksasa yang berbadan banteng dan bertempat tinggal di kerajaan Goa Kiskenda. Jatasura juga menjadi tunggangan Prabu Maesasura. Keberadaan binatang banteng juga menghiasi pada Gunungan wayang. Banteng digambarkan berhadapan dengan macan. Banteng menjadi simbol kejujuran dan kekuatan, pantang menyerah demi tujuan yang suci. Sifat banteng dapat dikekang pada hidungnya namun sekali bangkit akan mengamuk. 


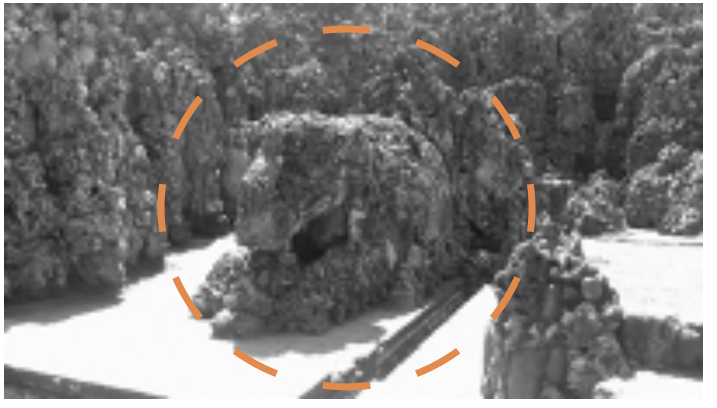

Gambar 3 Patung gajah rebahan di Taman Sunyaragi

Cagar budaya berikutnya adalah Taman Sunyaragi. Taman Sunyaragi merupakan tamansari dan pesang-grahan milik Keraton Kasepuhan Cirebon yang terletak di luar lingkungan keraton sebelah Tenggara. Taman tersebut berbentuk bangunan berongga dan memiliki lorong-lorong yang berliku seperti labirin dan gelap sehingga dikenal juga dengan nama Goa Sunyaragi. Taman dan bangunan yang dibuat dengan susunan bebatuan dan karang (wadasan) menyerupai perbukitan yang mengingatkan pada Mahameru. Istilah 'sunya' berarti sepi/sunyi, sedangkan 'ragi' berarti raga/jiwa karena memang tempat ini dibuat untuk dipakai raja beserta keluarganya untuk menyepi[13, 18]. Dalam proses pembuatannya ada beberapa tahapan. Tahapan-tahapan pembangunannya bisa terlihat dari kehadiran Candrasengkala.

Di depan Goa Peteng terdapat Candrasengkala berupa patung gajah sedang duduk (rebahan) dengan posisi belalai seakan menyemburkan air. Pada awalnya area ini merupakan petirtaan dimana pada bagian belalai sebagai pancuran airnya. Patung berbahan batu bercampur dengan karang (wadasan). Candrasengkala tersebut berbunyi "Gajah Derum Tirta Linuwih", gajah derum semacam rebahan di air yang berlebih. Gajah:8, derum:5, tirta:4, dan linuwih:1 sehingga tersusun angka tahun 1458 Saka atau 1536 M.

Gajah atau nama lainnya 'liman' kemungkinan dikaitkan dengan mitos gajah Airawata kendaraan dewa Indra yang bersemayam di puncak Mahameru (Indrakila). Airawata ber-saudara dengan gajah Puspadhenta kepunyaan Baladewa. Gajah Airawata berasal dari Samudra Mantana (kisah Mahabarata). Dalam budaya Timur, binatang gajah sering dikaitkan dengan raja dan otoritas kerajaan. Gajah juga melambangkan kekuatan, kebijaksanaan, kebajikan, jiwa besar, pelindung dan cinta kasih. Perlambangan tersebut dipakai untuk merefleksikan kepribadian Sultan Cirebon dan keturunannya[13, 19].

Dalam Sengkalan Memet, binatang gajah berwatak bilangan delapan, dimana jika terjurai dari badannya ada delapan bagian, antaralain: kaki empat, ekor satu, gading dua, dan belalai satu. Dari bagian badan tersebut jika dijumlahkan menjadi delapan. Gajah juga dianggap sekaum dengan ular yang juga berwatak bilangan delapan[5].

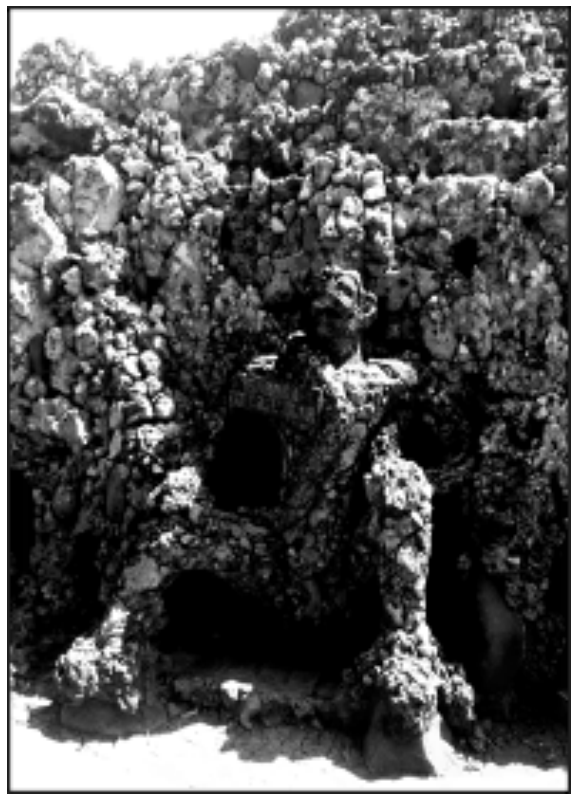


Pada area lainnya terdapat relief dengan figur garuda dililit ular. Relief yang dibuat dari susunan batu dan karang. Candrasengkala tersebut berbunyi "Bujangga Ratu Obahing Bumi" atau diterjemahkan dalam bahasa Indonesia Ular Raja Penggerak Bumi. Bujangga(ular):8, Ratu:1, Obah:6, dan Bumi:1, sehingga dibaca tahun 1618 Saka atau $1696 \mathrm{M}$.

Relief garuda dililit ular naga merupakan kisah mitologi Hindu 'Garudeya' yang mengisahkan usaha garuda membebaskan ibunya (Winata) dari perbudakan keluarga ular naga (Kadru). Kisah Garudeya sebelumnya terdapat pada bangunan candi-candi jaman pra Islam, yakni: pada candi Kidal dan candi Sukuh. Secara simbolik garuda melambangkan dunia atas sedangkan ular naga melambangkan dunia bawah. Keduanya merupakan kelengkapan sebagai kesimbangan. Seperti halnya keraton tempat tinggal Sultan, 'tetenger' atau simbol bertemunya dunia atas dengan dunia bawah dihadirkan pada Taman Sunyaragi[20].

Sebutan 'Bujangga' (bhujaga) - adalah ular jantan. Istilah 'bujangga' juga mengarah kepada 'pujangga' dimana sebutan bagi seseorang yang memiliki delapan kelebihan daripada orang pada umumnya. Karena seorang pujangga mempunyai: paramasastra (paham tata bahasa), parama kawi (paham berpuisi), awicarita (mahir membawakan cerita), mardawa lagu (pandai berlagu), mardi basa (paham seluk beluk bahasa), mandraguna (menguasai berbagai ilmu), nawung kridha (pandai bergaul), dan sambegana (pantas dicontoh hidupnya)[5]. Ular juga sama seperti gajah berwatak bilangan delapan.

\section{KESIMPULAN}

Keraton Kasepuhan Cirebon beserta Taman Sunyaragi dibangun dengan keragaman budaya yang unik dan khas. Salah satu hasil akulturasi budayanya adalah Sengkalan Memet (Candrasengkala). Sengkalan Memet merupakan bentuk pemikiran serta kreatifitas para leluhur. Mereka mewariskan pengetahuan, nilai falsafah, dan harapan melalui artefak yang tidak hanya bermakna angka tahun saja namun nilai pengajaran untuk generasi berikutnya. Cara penyampaian pesan dan nilai pengajaran yang unik, disajikan secara estetik, dan simbolik.

Penggunaan Sengkalan Memet pada jaman sekarang masih relevan dimana unsur kekayaan lokal dapat menjadi nilai tambah (added value) pada era global. Untuk itu bagi seniman, arsitek, desainer, maupun pelaku industri kreatif lainnya dapat memanfaatkannya sebagai pen-dekatan dalam perancangan karya. Kekayaan kearifan lokal perlu terus dikembangkan sebagai sumber ide yang tiada habisnya.

\section{DAFTAR PUSTAKA}

[1]. Harsojo Pengantar Antropologi. Bandung: Bina Cipta, 1984.

[2]. Herusatoto, B. Simbolisme dalam budaya Jawa. Yogyakarta: Hanindita Grahawidia, 2000. Epub ahead of print 2000. DOI: 306.1095982.

[3]. Ronald, A. Ciri-ciri karya budaya di balik tabir keagungan rumah Jawa. Yogyakarta: Universitas Atma Jaya Yogyakarta, 1997.

[4]. Daliman, A. Makna Sengkalan Sebagai Dinamika Kesadaran Historis : Kajian Filosofis Historis Keraton Yogyakarta. Yogyakarta. Yogyakarta: Ombak, 2012.

[5]. Bratakesawa, R. \& Hadisoeprapta, T.W.K. Keterangan Candra Sengkala. Jakarta, Indonesia: Proyek Penerbitan Buku Bacaan dan Sastra Indonesia dan Daerah, 1980.

[6]. Sudadi Sengkalan : Angka Tahun Di Balik Ungkapan Jawa. Jakarta, Indonesia: Kementerian Pendidikan dan Kebudayaan Badan Pengembangan dan Pembinaan Bahasa, 2018.

[7]. Macaryus, S. Sengkalan :Tinjauan Struktur dan Isi. Jurnal IImiah SINTESIS, 2007; 5: 187-204.

[8]. Ekomadyo, A.S. Pendekatan Semiotika Dalam Kajian Terhadap Arsitektur Tradisional Di Indonesia -Kasus Sengkalan Memet dalam Arsitektur Jawa. Seminar Nasional Naskah Arsitektur Nusantara: Jelajah Penalaran Arsitektural.

[9]. Sunaryo, A. Seni, Seni Rupa Nusantara Pengantar Kajian dan Apresiasi. Semarang: Dahara Prize, 2018.

[10]. Ekadjati, E.S. Sunan Gunung Jati : penyebar dan penegak Islam di tatar Sunda. 1st ed. Jakarta, Indonesia: Pustaka Jaya, 2005.

[11]. Adi, F.W.A. Sengkalan, Makna Penanda Dalam Bentuk Kalimat Atau Gambar Indah Sebagai Bahasa Komunikasi Seni. Corak, 2013; 2: 70-75.

[12]. Cirebon, P. Situs Cirebon. CirebonKota.go.id, https://www.cirebonkota.go.id/profil/sejarah/ sejarah-keraton/ (2020, accessed 24 April 2020).

[13]. Zuhdi, S. Cirebon sebagai bandar jalur sutra : kumpulan makalah diskusi ilmiah. In: Susanto 
(ed) Proyek Inventarisasi dan Dokumentasi Sejarah Nasiona. Jakarta, Indonesia: Direktorat Jenderal Kebudayaan, Departemen Pendidikan dan Kebudayaan, 1996, p. J.

[14]. Koentjaraningrat Kebudayaan Jawa. Jakarta: Balai Pustaka, 1984.

[15]. Agustina, I.H. Hindersah, H. \& Asiyawati, Y. Identifikasi Simbol-Simbol Heritage Keraton Kasepuhan. ETHOS (Jurnal Penelitian dan Pengabdian), 2017; 5: 167.

[16]. Holt, C. Melacak Jejak Perkembangan Seni di Indonesia. Bandung: arti.line, 2000.

[17]. Tabrani, P. Bahasa Rupa. Bandung: Kelir, 2005.

[18]. Lombard, D. Nusa Jawa: Silang Budaya - Kajian Sejarah terpadu. Jakarta, Indonesia: Gramedia Pustaka Utama, 1996.

[19]. Sulendraningrat, P.S. Sejarah Cirebon. Jakarta, Indonesia: Departemen Pendidikan dan Kebudayaan, Proyek Penerbitan Buku Bacaan dan Sastra Indonesia dan Daerah, 1978.

[20]. Putri, R.H. Garuda Sebelum Jadi Lambang Negara. Historia.id, https://historia.id/history-inone-minute/articles/garuda-sebelum-jadi-lambang-negara-PMayr (2019, accessed 27 April 2020). 